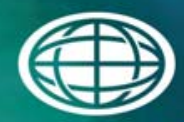

Savannah River

National Laboratory

\title{
Solvent Hold Tank Sample Results for MCU-13-1403/1404/1405/1406/1407/1408: Quarterly Sample from September 2013
}

\section{F. F. Fondeur}

K. M. L. Taylor-Pashow

November 2013

SRNL-STI-2013-00661, Revision, 0 
SRNL-STI-2013-00661

Revision 0

\section{DISCLAIMER}

This work was prepared under an agreement with and funded by the U.S. Government. Neither the U.S. Government or its employees, nor any of its contractors, subcontractors or their employees, makes any express or implied:

1. warranty or assumes any legal liability for the accuracy, completeness, or for the use or results of such use of any information, product, or process disclosed; or

2. representation that such use or results of such use would not infringe privately owned rights; or

3. endorsement or recommendation of any specifically identified commercial product, process, or service.

Any views and opinions of authors expressed in this work do not necessarily state or reflect those of the United States Government, or its contractors, or subcontractors.

\section{Printed in the United States of America}

Prepared for

U.S. Department of Energy 
Keywords: $M C U, A R P, I S D P$

Retention: Permanent

\section{Solvent Hold Tank Sample Results for MCU-13- 1403/1404/1405/1406/1407/1408: Quarterly Sample from September 2013}

F. F. Fondeur

K. M. L. Taylor-Pashow

November 2013

Prepared for the U.S. Department of Energy under contract number DE-AC09-08SR22470.

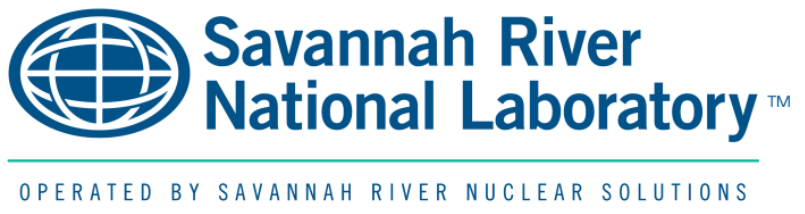

OPERATED BY SAVANNAH RIVER NUCLEAR SOLUTIONS 


\section{REVIEWS AND APPROVALS}

\section{AUTHORS:}

F. F. Fondeur, Author, SRNL/SASP

Date

K. M. L. Taylor-Pashow, Author, SRNL/SASP

Date

TECHNICAL REVIEW:

C. A. Nash, Technical Reviewer, SRNL/ACP (Reviewed per E7 2.60)

Date

APPROVAL:

F. M. Pennebaker, ADV Characterization \& Process, Manager

Date

S. L. Marra, SRNL/E\&CPT Research Programs, Manager

Date

D. J. Martin, H Tank Farm Process Engineering

Date 


\section{EXECUTIVE SUMMARY}

Savannah River National Laboratory (SRNL) analyzed solvent samples from the Modular Caustic-Side Solvent Extraction Unit (MCU) in support of continuing operations. A quarterly analysis of the solvent is required to maintain solvent composition within specifications. Analytical results of the analyses of Solvent Hold Tank (SHT) samples MCU-13-1403, MCU-13-1404, MCU-13-1405, MCU-13-1406, MCU-13-1407, and MCU-13-1408 received on September 17, 2013 are reported. This sample was taken after the addition of the Next Generation Solvent (NGS) cocktail to produce a NGS-MCU blended solvent.

The results show that the solvent contains a slight excess of Isopar ${ }^{\circledR} \mathrm{L}$ and a deficit concentration of modifier and TiDG when compared to the target composition. Addition of TiDG trim is recommended.

SRNL also analyzed the SHT sample for ${ }^{137}$ Cs content and determined the measured value is within tolerance and that the value has returned to levels observed in 2011.

In contrast to what was observed in the heel prior to adding the NGS cocktail, no organic impurities were detected in these solvent samples. 


\section{TABLE OF CONTENTS}

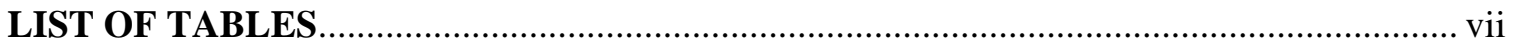

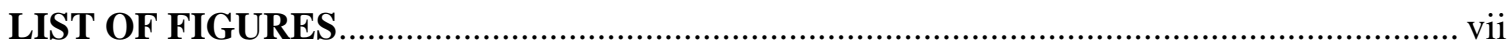

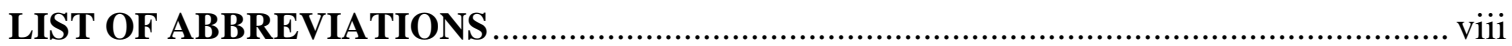

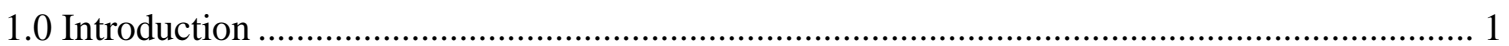

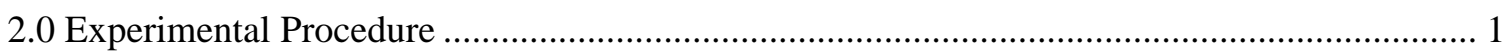

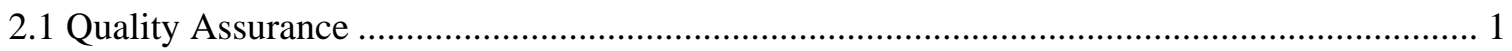

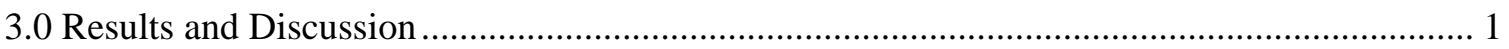

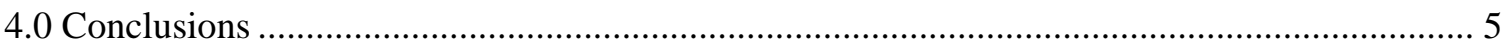

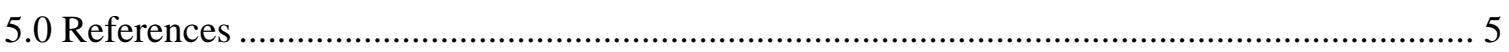

Appendix A. Correspondence on the effect of TOA/TiDG on third phase formation ....................6 


\section{LIST OF TABLES}

Table 1. Sample Results for MCU-13-1403, MCU-13-1404, MCU-13-1405, MCU-13-1406, MCU-13-1407, and MCU-13-1408 Composite 3

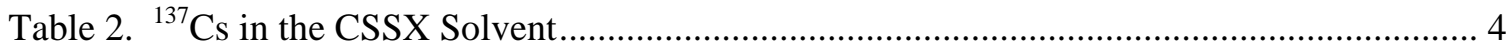

\section{LIST OF FIGURES}

Figure 1. The gamma count of selected SHT samples. One standard deviation is 5\%. 4 


\section{LIST OF ABBREVIATIONS}

\begin{tabular}{|c|c|}
\hline BOBCalixC6 & Calix[4]arene-bis(tert-octylbenzo-crown-6) \\
\hline CSSX & Caustic Side Solvent Extraction \\
\hline ESS & Extraction, Scrub, and Strip \\
\hline FID & Flame Ionization Detector \\
\hline FT-HNMR & Fourier Transform Hydrogen Nuclear Magnetic Resonance \\
\hline FTIR & Fourier transform infra-red spectroscopy \\
\hline HPLC & High Performance Liquid Chromatography \\
\hline ISDP & Integrated Salt Disposition Project \\
\hline MCU & Modular Caustic-Side Solvent Extraction Unit \\
\hline MaxCalix & $\begin{array}{l}\text { 1,3-alt-25,27-Bix(3,7-dimethyloctyloxy)calix[4]arene-benzocrown- } \\
6\end{array}$ \\
\hline NGS & Next Generation Solvent \\
\hline RSD & $\begin{array}{l}\text { Relative Standard Deviation or the absolute value of the Coefficient } \\
\text { of Variation }\end{array}$ \\
\hline SHT & Solvent Hold Tank \\
\hline SRNL & Savannah River National Laboratory \\
\hline SVOA & Semi-Volatile Organic Analysis \\
\hline TiDG & $N, N$ ', $N$ ”-tris(3,7-dimethyloctyl)guanidine \\
\hline TOA & Trioctylamine \\
\hline
\end{tabular}




\subsection{Introduction}

Solvent Hold Tank (SHT) samples are sent to Savannah River National Laboratory (SRNL) to examine solvent composition changes over time. ${ }^{1}$ Recently, MCU entered a planned outage to implement the NGS flowsheet. In turn, facility personnel added a nonradioactive "cocktail" solvent containing the new extractant (MaxCalix) and a new suppressor (TiDG) to the SHT heel. NGS levels within the "cocktail" were such that when added to in equal volume would result in $~ 50 / 50$ CSSX-NGS solvent blend. On September 17, 2013, Operations personnel delivered six samples from the SHT (MCU13-1403, MCU-13-1404, MCU-13-1405, MCU-13-1406, MCU-13-1407, and MCU-131408) for analysis. These samples are intended to verify that the solvent is within the specified composition range. A baseline "scratch" solvent (a blend of NGS “cocktail”"2 and CSSX heel solvent ${ }^{3}$ ) was prepared in the lab and used for comparison and evaluation. The results from the analyses are presented in this document.

\subsection{Experimental Procedure}

Samples were received in p-nut vials containing $\sim 10 \mathrm{~mL}$ each. Once taken into the Shielded Cells, the samples were visually inspected, analyzed for $\mathrm{pH}$, combined and mixed. Samples were removed for analysis by density, semi-volatile organic analysis (SVOA), high performance liquid chromatography (HPLC), titration, gamma counting, Fourier-Transform Hydrogen Nuclear Magnetic Resonance (FT-HNMR) and FourierTransform Infra-Red spectroscopy (FTIR).

\subsection{Quality Assurance}

Requirements for performing reviews of technical reports and the extent of review are established in manual E7 2.60. SRNL documents the extent and type of review using the SRNL Technical Report Design Checklist contained in WSRC-IM-2002-00011, Rev. 2. Details for the work are contained in a controlled laboratory notebook. ${ }^{4}$

\subsection{Results and Discussion}

Each of the six p-nut vials contained a single phase, with no apparent solids contamination or cloudiness. All samples had a $\mathrm{pH}$ value of 10 . Table 1 contains the results of the analyses for the combined sample.

A triplicate density measurement of the organic phase gave a result of $0.826 \mathrm{~g} / \mathrm{mL}$ $\left(0.24 \%\right.$ RSD) at $23{ }^{\circ} \mathrm{C}$ (or $0.8243 \mathrm{~g} / \mathrm{mL}$ at $25{ }^{\circ} \mathrm{C}$ when corrected for temperature). The calculated density $(0.8243 \mathrm{~g} / \mathrm{mL})$ is lower than the calculated density obtained from the Sept 4, 2013 sample. $^{3}$ This is expected since the current CSSX solvent was blended with a lower density solvent formulation (NGS). The calculated density is lower than the calculated standard density for the 50/50 CSSX-NGS blended solvent $(0.8294 \mathrm{~g} / \mathrm{mL})$. Using the density as a starting point, we know that the Isopar ${ }^{\circledR} \mathrm{L}$ should be slightly higher than nominal and the other components should be slightly lower than nominal. This confirms a slight excess of Isopar ${ }^{\circledR} \mathrm{L}$ in this batch.

The analytical data for the composite sample is shown in Table 1. Of all the methods listed, density has the lowest uncertainty. With the exception of the SVOA data, the 
results as a whole are internally consistent between methods for Isopar ${ }^{\circledR} \mathrm{L}$ and Modifier* The density result is confirmed by the FTIR and FT-HNMR results which are separate methods. With the exception of the SVOA method, all measurements indicate Isopar ${ }^{\circledR} \mathrm{L}$ slightly higher than nominal, and Modifier lower than nominal. The total mass sum of the "average" results per liter listed in Table 1 adds up to $8.31 \mathrm{E} 5 \mathrm{mg} / \mathrm{L}$ which compares well with the mass concentration of the standard per liter $(8.29 \mathrm{E} 5 \mathrm{mg} / \mathrm{L})$. As indicated in Table 1, the Modifier and Isopar ${ }^{\circledR} \mathrm{L}$ concentrations are consistent within the noise of sample handling and method uncertainties. The SVOA method measured a modifier concentration of $120 \mathrm{E} 3 \mathrm{mg} / \mathrm{L}$. This value is $78 \%$ of the value measured by the other methods and therefore, it was not used in Table 1 (the SVOA method has been found to be less reliable for measuring the modifier).

The MaxCalix concentration is slightly above the expected value while the BobCalix concentration is within its nominal value. The suppressor ( $\mathrm{TiDG} * \mathrm{HCl}$ or in the chloride form) concentration is well below ( 67\%) the expected value $(1.55 \mathrm{E} 3 \mathrm{mg} / \mathrm{L})$. The reason for this lower value is unknown at this time but improper mixing, inadequate TiDG addition, dilution (due to excess Isopar ${ }^{\circledR} \mathrm{L}$ ), and/or TiDG decomposition may have contributed to the lower value. The other suppressor, TOA, concentration was within its nominal value.

Reduced levels of TOA and/or TiDG will not lead to third formation (see Appendix A). The current level of TiDG may be insufficient to prevent anionic impurities from pairing with cesium, preventing cesium stripping, and increasing the activity level in the solvent. It is prudent to add a TiDG trim to the solvent.

When compared to target density of $0.829 \mathrm{~g} / \mathrm{mL}$, there is no need to add an Isopar $^{\circledR} \mathrm{L}$ trim.* However, addition of TiDG may be prudent. As the Isopar ${ }^{\circledR} \mathrm{L}$ evaporates the modifier levels will increase to the nominal value.

A further evaluation of the FTIR and FT-HNMR data from this solvent revealed no impurities at the $20 \mathrm{ppm}$ level. The addition of the NGS cocktail has diluted the previously observed impurity containing an aldehyde group in the heel sample. ${ }^{3}$ No nonsolvent organic components were observed by SVOA at $1000 \mathrm{mg} / \mathrm{L}$ or higher.

In addition to the organic analysis, SRNL measured the ${ }^{137} \mathrm{Cs}$ activity of the solvent. See Table 2 for these results. This measurement is used as an indication of whether or not the solvent is being properly stripped of cesium. In this case, assuming this gamma result is correct the measured gamma is twice the gamma measurement of the previous sample. ${ }^{3}$ The analytical uncertainty for this measurement is $5 \%$.

\footnotetext{
${ }^{*}$ Modifier is (1-(2,2,3,3-tetrafluoropropoxy)-3-(4-sec-butylphenoxy)-2-propanol, also known as Cs-7SB, is added to increase solubility of the extractant.

* Note that while freshly prepared blend solvent has a target density of $0.829 \mathrm{~g} / \mathrm{mL}$, the MCU facility targets to maintain the solvent inventory at lower densities to allow longer operating periods before correcting for evaporation.
} 
Table 1. Sample Results for MCU-13-1403, MCU-13-1404, MCU-13-1405, MCU-131406, MCU-13-1407, and MCU-13-1408 Composite

\begin{tabular}{|c|c|c|c|c|c|}
\hline Analysis & Method & LIMS \# & $\begin{array}{l}\text { Result } \\
(\mathrm{mg} / \mathrm{L})^{\#}\end{array}$ & $\begin{array}{c}\text { Nominal }^{*} \\
\text { Result } \\
(\mathrm{mg} / \mathrm{L})\end{array}$ & $\begin{array}{l}\% \text { of (Result } \div \\
\text { Nominal Result) }\end{array}$ \\
\hline Isopar $^{(R)} \mathrm{L}$ & SVOA & 300306802 & $640 \mathrm{~F} 3$ & $613 \mathrm{E3}$ & $104 \%$ \\
\hline Isopar $\left.^{(}\right) \mathrm{L}$ & FT-HNMR & NA & 634 E3 & $613 \mathrm{E3}$ & $103 \%$ \\
\hline Isopar $^{(B)} \mathrm{L}$ & FTIR & NA & 630 E3 & 613 E3 & $103 \%$ \\
\hline Isopar ${ }^{\circledR} \mathrm{L}$ & Density $^{*}$ & NA & 620 E3 & 613 E3 & $101 \%$ \\
\hline Average & all & NA & $6.23 \mathrm{E} 5$ & $6.13 \mathrm{E} 5$ & $102 \%^{\$}$ \\
\hline Modifier & HPLC & 300306802 & 154 E3 & $166 \mathrm{E} 3$ & $93 \%$ \\
\hline Modifier & FT-HNMR & NA & 154 E3 & $166 \mathrm{E} 3$ & $93 \%$ \\
\hline Modifier & FTIR & NA & $151 \mathrm{E} 3$ & $166 \mathrm{E} 3$ & $91 \%$ \\
\hline Modifier & Density $^{*}$ & NA & 155 E3 & $166 \mathrm{E} 3$ & $93 \%$ \\
\hline Average & all & NA & $1.53 \mathrm{E} 5$ & $166 \mathrm{E} 3$ & $92 \% \$$ \\
\hline TiDG (HCl) & Titration & NA & $1.12 \mathrm{E} 3$ & $1.55 \mathrm{E} 3$ & $72 \%$ \\
\hline TiDG (HCl) & FT-HNMR & NA & $0.81 \mathrm{E} 3$ & $1.55 \mathrm{E} 3$ & $52 \%$ \\
\hline Average & All & NA & $1.0 \mathrm{E} 3$ & $1.55 \mathrm{E} 3$ & $67 \% \$$ \\
\hline trioctylamine & SVOA & 300306802 & 440 & $0.53 \mathrm{E} 3$ & $83 \%$ \\
\hline trioctylamine & Titration & NA & 562 & $0.53 \mathrm{E} 3$ & $106 \%$ \\
\hline Average & All & NA & 527 & 0.53 E3 & $99 \% \$$ \\
\hline MaxCalix & HPLC & 300306802 & $47.9 \mathrm{E} 3$ & $44 \mathrm{E3}$ & $109 \%$ \\
\hline MaxCalix & FT-HNMR & NA & $52.0 \mathrm{E} 3$ & $44 \mathrm{E} 3$ & $118 \%$ \\
\hline Average & All & NA & $49.4 \mathrm{E} 3$ & 44 E3 & $112 \%^{\$}$ \\
\hline BobCalix & HPLC & 300306802 & $3.9 \mathrm{E} 3$ & 4 E3 & $98 \%$ \\
\hline $\begin{array}{l}\text { Density } \\
\text { (g/mL) }\end{array}$ & $\begin{array}{c}\text { Direct } \\
\text { measurement }\end{array}$ & NA & 0.824 & 0.829 & $99.4 \%$ \\
\hline
\end{tabular}

\# Analytical uncertainty is $20 \%$ for SVOA and 10\% for HPLC. FTIR analytical uncertainty is $15 \%$ for Isopar $^{\circledR} \mathrm{L}$ and $10 \%$ for Modifier. Titration method uncertainty is $10 \%$. Density results from the average of replicate volumetric trials typically have a percentage standard deviation of $<3 \%$ between each value and the average. NMR analytical uncertainty is $10 \%$ for the modifier and MaxCalix, $14 \%$ for Isopar $^{\circledR} \mathrm{L}$, and $20 \%$ for TiDG. 
* Nominal value is the expected value for freshly prepared blended solvent with a target density of $0.829 \mathrm{~g} / \mathrm{mL}$ at $25^{\circ} \mathrm{C}$.

$\$ x=\frac{\sum_{1}^{i}\left(x_{i} / \delta_{i}^{2}\right)}{\sum_{1}^{i}\left(1 / \delta_{i}^{2}\right)} ; \quad \begin{aligned} & x_{i} \text { stands for the concentration obtained at a given } \\ & \text { method and } \delta_{i} \text { is the corresponding uncertainty. }\end{aligned}$

NA = Not Applicable

Table 2. ${ }^{137} \mathrm{Cs}$ in the CSSX Solvent

\begin{tabular}{|c|c|}
\hline Analyte & Result $(\mathbf{d p m} / \mathbf{m L})$ \\
\hline${ }^{137} \mathrm{Cs}$ & $4.21 \mathrm{E}+05$ \\
\hline
\end{tabular}

The ${ }^{137}$ Cs result shown in Table 2 is double the previous measurement despite the solvent being a blend between a cesium-containing heel and a non-radioactive solvent (cocktail). ${ }^{2}$ This data may indicate, if it is correct, that additional cesium loaded onto the blended solvent from within the facility during the mixing process (blending process).

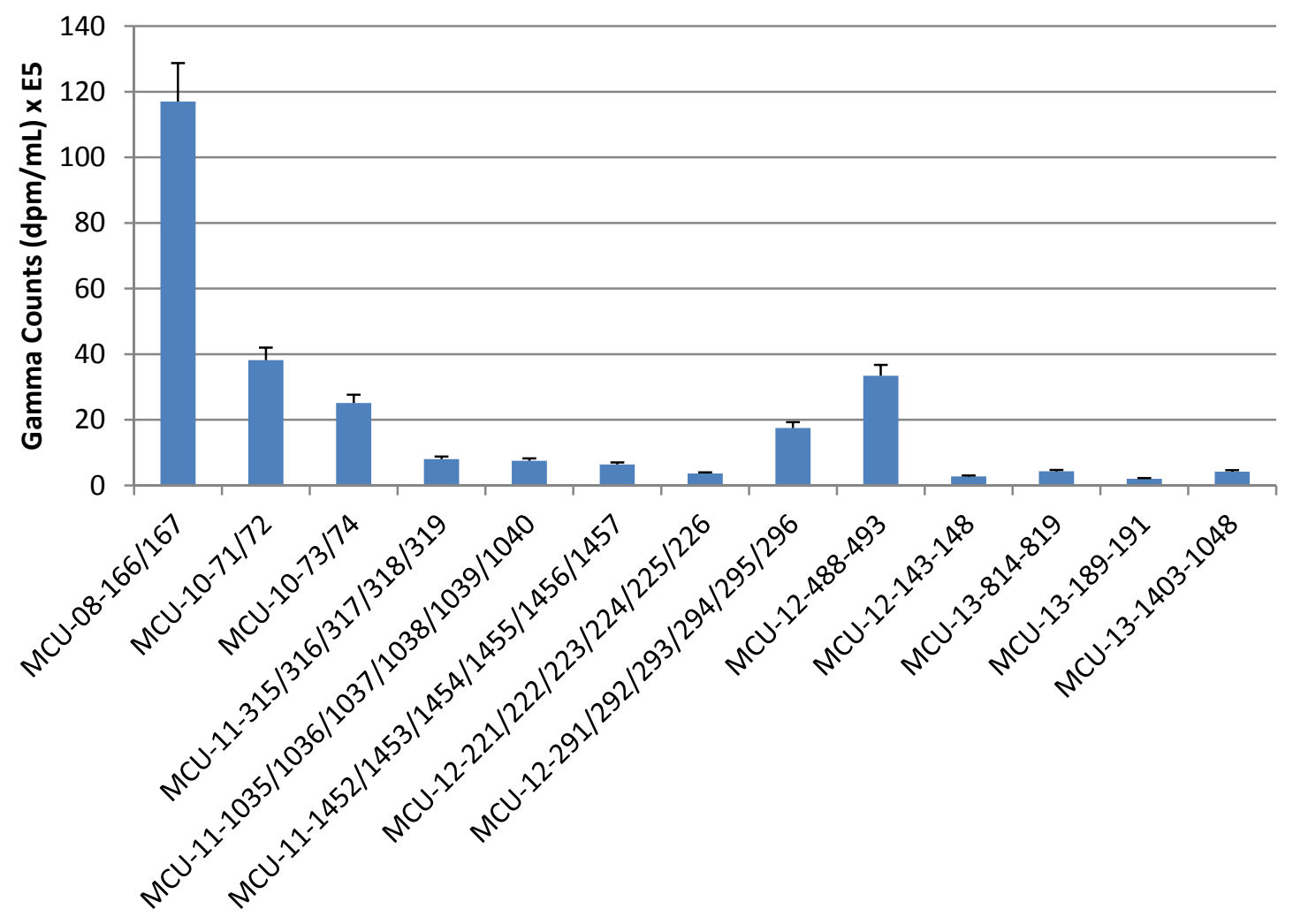

Figure 1. The gamma count of selected SHT samples. One standard deviation is $\mathbf{5 \%}$. 


\subsection{Conclusions}

As with the previous solvent sample results, these analyses indicate that the solvent does not require Isopar ${ }^{\circledR} \mathrm{L}$ trimming at this time. However, the addition of TiDG (suppressor) to the blended solvent is recommended. No organic impurities were detected in this solvent.

\subsection{References}

${ }^{1}$ W. M. Matthews, HLW-CRF-10006, Rev. 0, May 18, 2010.

${ }^{2}$ T. B. Peters and M. R. Williams, "Results of Analysis of NGS Concentrate Drum Samples” SRNL-STI-2013-00521, September 2013.

${ }^{3}$ F. F. Fondeur and K. M. Taylor-Pashow, "Solvent Hold Tank Sample Results for MCU13-189/190/191: Quarterly Sample from September 2013, SRNL-STI-2013-00652, October 2013.

${ }^{4}$ T. B. Peters, “ISDP4”, SRNL-NB-2011-00027, February 18, 2011. 
Appendix A: Correspondence on the effect of TOA/TiDG on third phase formation

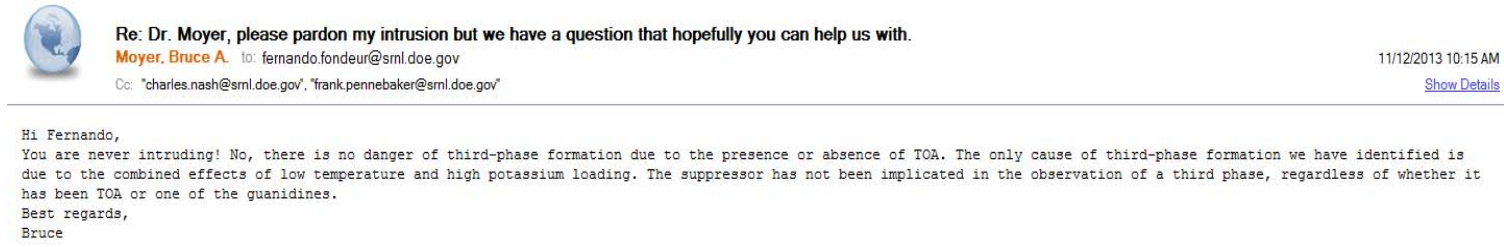




\section{Distribution:}

T. B. Brown, 773-A

S. D. Fink, 773-A

C. C. Herman, 999-W

E. N. Hoffman, 999-W

S. L. Marra, 773-A

D. H. McGuire, 999-W

F. M. Pennebaker, 773-42A

W. R. Wilmarth, 773-A

M. T. Keefer, 704-56H

D. J. Martin, 241-152H

B. A. Gifford, 704-56H

Q. L. Nguyen, 241-152H

T. E. Smith, 241-152H

E. A. Brass, 241-121H

T. B. Peters, 773-42A

C. A. Nash, 773-42A

F. F. Fondeur, 773-A

K. M. L. Taylor-Pashow, 773-A

P. R. Jackson, 703-46A 